\title{
20 ANOS PODEM ALTERAR A DISTRIBUIÇÃO TEMPORAL DO CARANGUEJO BAÚ HEPATUS PUDIBUNDUS (HERBST, 1785) (DECAPODA, AETHROIDEA) NO LITORAL SUDESTE DO BRASIL?
}

\author{
Teles, J.N. ${ }^{1,}$; Rodrigues, G.F.B. ${ }^{1}$; Martins, F.K. ${ }^{\text {; }}$ Bernardes, V.P. ${ }^{1}$; Godoy, A.T. ${ }^{1}$; \\ Silva, D.M.R. ${ }^{1}$; Bernardo, C.H. ${ }^{1}$ \& Sousa, A.N. ${ }^{1}$ \\ ${ }^{1}$ Universidade Estadual Paulista (UNESP), Campus Botucatu, Instituto de Biociências, Departamento de Zoologia, \\ Núcleo de Estudos em Biologia, Ecologia e Cultivo de Crustáceos (NEBECC), São Paulo, Brasil. \\ *Autor correspondente: jenifferteles94@gmail.com
}

\begin{abstract}
Apesar de não possuir valor econômico, o caranguejo Hepatus pudibundus possui um importante valor ecológico na cadeia trófica, pois tem a maior biomassa de caranguejos capturados como by-catch nas pescas de arrasto da região de Ubatuba. O objetivo foi analisar a distribuição temporal de H. pudibundus em dois períodos distinto, com o intervalo de 20 anos. Os crustáceos foram coletados com um barco de pesca camaroeiro, equipado com redes do tipo "double-rig", em cinco áreas amostrais $\left(5 \mathrm{~m}, 10 \mathrm{~m}, 15 \mathrm{~m}\right.$, batido e abrigado). A coleta do $1^{\circ}$ período ( $\left.{ }^{\circ} \mathrm{P}\right)$ ocorreu de setembro/1995 a agosto/1996, e o $2^{\circ}$ período $\left(2^{\circ} \mathrm{P}\right)$ de setembro/2016 a agosto/2017. Também foram coletadas amostras de água para verificar temperatura e salinidade de fundo, cujo a média de valores de cada estação foi comparada entre os períodos pelo teste $t$ de Student. A análise de correspondência (CA), foi realizada para verificar a relação entre os grupos demográficos (juvenis, fêmeas e machos adultos) e as estações do ano. Foi capturado um total de 865 espécimes no $1^{\circ} \mathrm{P}$ e 4.222 no $2^{\circ} \mathrm{P}$. Somente o verão não apresentou diferenças entre a temperatura e salinidade entre os períodos $(p<0.05)$. Os valores de salinidade no $2^{\circ} \mathrm{P}$ foram maiores do que no $1^{\circ} \mathrm{P}$, exceto nos meses de dezembro e março. A temperatura foi maior no verão, primavera e final do inverno do $2^{\circ} \mathrm{P}$. Os juvenis apresentaram relação com a primavera do $1^{\circ} \mathrm{P}$ e inverno do $2^{\circ} \mathrm{P}$. Já os machos e fêmeas adultas do $1^{\circ} \mathrm{P}$ relacionaram-se com a primavera, enquanto que no $2^{\circ} \mathrm{P}$, as fêmeas adultas foram associadas com o verão, e os machos adultos permaneceram na primavera. Houve uma mudança significativa na distribuição temporal de juvenis e fêmeas adultas. A relação dos juvenis com o inverno pode ser uma estratégia reprodutiva, para evitar a competição, uma vez que a maioria dos crustáceos decápodes na região tem um pico de recrutamento no verão e primavera. Além do mais, as fêmeas tiveram associação com o verão, no qual a temperatura da água de fundo é mais elevada, o que ajuda as fêmeas no processo de desenvolvimento das gônadas e também pode proporcionar melhor nutrição para os embriões, uma vez que no verão a produtividade primária é maior. Conclui-se que em 20 anos houve uma mudança na distribuição temporal da espécie na Enseada de Ubatuba, o que foi positivo para a população de H. pudibundus, já que houve um aumento significativo em sua abundancia.
\end{abstract}

Palavras-chave: Crustacea, estações, intervalo de tempo, grupos demográficos, Ubatuba. 